\title{
Effect of Lactococcus garvieae, Lactococcus lactis and Enterococcus faecalis on the behaviour of Staphylococcus aureus in microfiltered milk
}

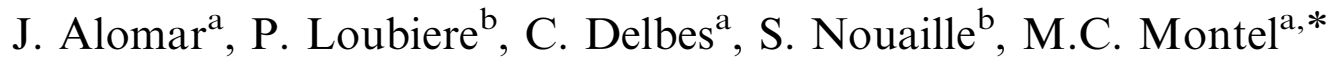 \\ ${ }^{\mathrm{a}}$ INRA, Unité Recherches fromagères, 36 rue de Salers, 15000 Aurillac, France \\ ${ }^{\mathrm{b}}$ Laboratoire Biotechnologie-Bioprocédés, INSA, UMR CNRS 5504, UMR INRA 792, 135 Avenue de Rangueil, 31077 Toulouse cedex 4, France
}

Received 26 March 2007; received in revised form 13 December 2007; accepted 8 January 2008

Available online 29 January 2008

\begin{abstract}
The effect of four strains of Lactococcus garvieae, three strains of Lactococcus lactis and one strain of Enterococcus faecalis on Staphylococcus aureus SA15 growth in microfiltered milk was evaluated. Lactococcus and Enterococcus strains were co-cultured with S. aureus in microfiltered milk and in medium buffered at $\mathrm{pH}$ 6.8. All Lactococcus and Enterococcus strains were able to inhibit $S$. aureus growth after $6 \mathrm{~h}$ of incubation. Inhibition by L. lactis and E. faecalis strains could be partially attributed to the decrease in $\mathrm{pH}$ below 6.0 as it has been observed in medium buffered at $\mathrm{pH}$ 6.8. L. garvieae strains were the most effective to inhibit $S$. aureus growth without acidification. Inhibition of $S$. aureus could not be attributed neither to production of lactate, acetate or nor to antistaphylococcal substance. Amino acids competition was not involved in the inhibition by L. garvieae as addition of valine, isoleucine, threonine, methionine and phenylalanine did not suppress the inhibition of $S$. aureus.
\end{abstract}

(C) 2008 Elsevier Ltd. All rights reserved.

Keywords: Staphylococcus aureus; Lactococcus; Enterococcus; Milk; Inhibition

\section{Introduction}

Safety of raw milk cheeses implies that the development of food borne pathogens be controlled, in compliance with European regulations. Staphylococcus aureus can be involved in Toxi-Infections Alimentaires Collectives (TIACs) involving milk and dairy products (De Buyser et al., 2001). In 2006, the European legislation laid down the obligation to determine the presence of enterotoxins in cheese if the level of $S$. aureus is over $10^{5} \mathrm{CFU} \mathrm{g}^{-1}$. Bacterial contamination of milk has been largely reduced by identifying the potential sources of $S$. aureus, leading to controlling mastitis in herds and applying hygienic practices (Sommerhauser et al., 2003; Chassagne et al., 2005). Nevertheless, the presence of bacterial species in milk cannot be avoided.

\footnotetext{
*Corresponding author. Tel.: + 33471456411 ; fax: + 33471456413 .

E-mail address: cmontel@clermont.inra.fr (M.C. Montel).
}

In spite of a low count in milk, its count during the first hours of cheesemaking may exceed that authorized by the legislation (Sesques, 1994; Meyrand et al., 1998; Lamprell, 2003). Therefore, S. aureus must be inhibited at a very early stage of the cheesemaking process. This can be achieved by strong acidification in cheese as $S$. aureus growth can stop in $6 \mathrm{~h}$ in non-cocked semi-hard cheeses with a $\mathrm{pH}$ value below 5.6 (Delbes et al., 2006). However, strong acidification may limit the growth and activities of other bacterial populations involved in the development of the sensorial properties of certain raw milk cheeses (Feeney et al., 2002; Callon et al., 2005).

S. aureus inhibition in culture media could also be achieved through bacteriocin production by Lactobacillus plantarum (Stecchini et al., 1991; Todorov et al., 1999; Hernandez et al., 2005) and Lactobacillus delbrueckii (Miteva et al., 1998). Nevertheless, the effectiveness of these bacteriocins in cheese is not well documented, even if inhibition by nisin produced by Lactococcus lactis, or 
enterocin produced by Enterococcus faecalis has been observed (Zottola et al., 1994; Hamama et al., 2002; Giraffa, 2003). The combination of high pressure treatments and bacteriocin-producing lactic acid bacteria (LAB) inhibited $S$. aureus growth in cheese (Arques et al., 2005). Such treatments may be difficult to apply in some cheese technologies, particularly for farm cheese production.

In purpose to use biopreservation for inhibiting $S$. aureus growth in raw-milk farm production, it is important to select starter cultures. Therefore, the aim of this study was to evaluate the effect of different strains of LAB commonly found in raw milk cheeses and belonging to L. lactis, E. faecalis and Lactococcus garvieae on $S$. aureus growth in microfiltered milk.

\section{Material and methods}

\subsection{Bacterial strains and culture conditions}

\subsubsection{Bacterial strains}

One strain of $S$. aureus SA15 isolated from raw milk was selected for this study. Four strains of L. garvieae (N201, Tan 1, Tan 2, and 1204), three of L. lactis subsp. lactis (N650, N658 and N688), and one strain of E. faecalis (N516) isolated from raw milk cheeses were selected to tested in cocultured with $S$. aureus in microfiltered milk. The strains of LAB were identified by $16 \mathrm{~S}$ ribosomal RNA gene sequencing as described by Callon et al. (2004) and their genomic diversity was assessed by REP-PCR (Jersek et al., 1999).

\subsubsection{Inoculum preparation}

2.1.2.1. Preparation of $S$. aureus inoculum. For the coculture in microfiltered milk, $S$. aureus was pre-cultured in BHI (Biokar Diagnostic, Pantin, France) broth modified by adding $12 \mathrm{gl}^{-1}$ of skimmed milk powder (Lactalis Industry, Bourgbarré, France) to pre-adapt the strain to its future incubation in milk. For the co-culture in TS buffered medium, S. aureus was pre-cultured in BHI (Biokar Diagnostic, Pantin, France). The cultures were incubated at $37^{\circ} \mathrm{C}$ during $18 \mathrm{~h}$. Then the cultures were centrifuged to $9600 \times \mathrm{g}$ for $15 \mathrm{~min}$ at $4{ }^{\circ} \mathrm{C}$ (SIGMA 3MK, Bioblock Scientific, Illkirch, France) and the cell pellet was washed once in Ringer solution (Biokar Diagnostic, Pantin, France) before inoculation into commercial microfiltered milk or TS buffered medium at level $150 \mathrm{CFU} \mathrm{ml}^{-1}$.

\subsubsection{Preparation of $L A B$ inoculum. For the co-culture} of LAB and $S$. aureus in microfiltered milk, each strain was pre-cultured from a frozen cell suspension in $9 \mathrm{ml}$ of skimmed milk ( $120 \mathrm{~g}$ of skimmed milk powder $\mathrm{l}^{-1}$ (Lactalis Industry) distilled water were sterilized at $115^{\circ} \mathrm{C}$ for $15 \mathrm{~min}$. After $18 \mathrm{~h}$ of incubation at $30^{\circ} \mathrm{C}, 1 \mathrm{ml}$ of the culture containing $1 \times 10^{10} \mathrm{CFU} \mathrm{m}^{-1}$ was inoculated into $100 \mathrm{ml}$ of full $\left(36 \mathrm{~g} \mathrm{fat}^{-1}\right)$ microfiltered milk (Marguerite) previously inoculated with $S$. aureus as described above.
L. garvieae N201, L. lactis $\mathrm{N} 658$ and E. faecalis N516 were pre-cultured in $9 \mathrm{ml}$ of M17 broth for $18 \mathrm{~h}$ at $30^{\circ} \mathrm{C}$ before their inoculation in TS buffered medium. Then the cultures were centrifuged to $9600 \times g$ for $15 \mathrm{~min}$ at $4{ }^{\circ} \mathrm{C}$ (Sigma 3MK). The cell pellet was washed once in Ringer solution (Biokar) before inoculation at final concentration of $1 \times 10^{8} \mathrm{CFU} \mathrm{ml}{ }^{-1}$ into TS buffered medium.

\subsubsection{Culture media}

$S$. aureus alone was cultivated in commercial full fat microfiltered milk (Marguerite, Villefranche sur Saône, ARNAS, France) at different initial $\mathrm{pH}$ values at $33^{\circ} \mathrm{C}$ for $24 \mathrm{~h}$. Milk was adjusted to $\mathrm{pH} 6.50,6.25,6.00,5.78$ and 5.60 with $90 \%$ lactic acid (Prolabo, Lyon, France), prior to inoculation.

The effect of the eight strains of LAB on $S$. aureus growth was tested in commercial full fat microfiltered milk (Marguerite, Villefranche sur Saône, ARNAS, France). In this milk was also studied the effect of addition of $10 \mu \mathrm{moll}^{-1}$ of methionine, threonine, phenylalanine, isoleucine and valine (MERCK, Darmstadt, Germany) on $S$. aureus growth in coculture with $L$. garvieae N201. These amino acids were selected as they were metabolized by $L$. garvieae N201 (see results in Table 2). They were prepared in distilled water and sterilized by filtration through a $0.45 \mu \mathrm{m}$-pore-size cellulose acetate filter (Minisart, Sartorius AG, Germany).

$S$. aureus was also co-cultivated with $L$. garvieae N201, L. lactis $\mathrm{N} 658$ or $E$. faecalis in TS medium containing $17 \mathrm{gl}^{-1}$ tryptone (Biokar Diagnostic, Pantin, France), $3 \mathrm{gl}^{-1}$ peptone (Biokar Diagnostic, Pantin, France), $6 \mathrm{gl}^{-1}$ yeast extract (Biokar Diagnostic, Pantin, France), $2.5 \mathrm{gl}^{-1}$ $\mathrm{K}_{2} \mathrm{HPO}_{4}$ (MERCK, Darmstadt, Germany), $5 \mathrm{gl}^{-1} \mathrm{NaCl}$ (Prolabo, Lyon, France). It was buffered at pH 6.8 with phosphate buffer $\quad \mathrm{KH}_{2} \mathrm{PO}_{4} / \mathrm{K}_{2} \mathrm{HPO}_{4} 0.1 \mathrm{~mol} \quad\left(\mathrm{KH}_{2} \mathrm{PO}_{4}\right.$, Prolabo; $\mathrm{K}_{2} \mathrm{HPO}_{4}$, Merck) to avoid the effect of decreasing the $\mathrm{pH}$ value of the medium on the growth of $S$. aureus.

\subsubsection{Conditions of incubation}

The milk inoculated with $S$. aureus alone as well as all co-cultures in microfiltered milk and buffered medium were incubated in water baths at temperatures simulating the decrease in temperature recorded during the cheese making process of some semi-hard cheeses such as Saint-Nectaire cheese. The evolution of temperature during the incubation was automatically drived and recorded by the software of CINAC system (YSEBAERT, Frepillon, France). At $0 \mathrm{~h}$, the temperature was $33^{\circ} \mathrm{C}$, and then gradually decreased to 30.5 at $3 \mathrm{~h} ; 27.3$ at $6 \mathrm{~h}, 24.6$ at $9 \mathrm{~h}, 22.9$ at $12 \mathrm{~h}, 21.0$ at $18 \mathrm{~h}$ and to $19^{\circ} \mathrm{C}$ after $24 \mathrm{~h}$ of incubation. $\mathrm{pH}$ values were recorded with CINAC (YSEBAERT). All the experiments were repeated three times for each strain of LAB.

\subsection{Staphylococcus aureus and lactic acid bacteria counts}

S. aureus and LAB strains were counted at $0,3,6$ and $24 \mathrm{~h}$. Milk and TS-buffered medium samples were homogenized with a stomacher Lab Blender (Seward Medical, 
London, UK) for a time optimised at 4 min for dissociating all the cell aggregates. After appropriate dilution in Ringer solution, $S$. aureus was enumerated on Rabbit Plasma Fibrinogen Agar (RPFA) (De Buyser et al., 2003) incubated for 24 at $37^{\circ} \mathrm{C}$. LAB were enumerated on M17 medium (Biokar Diagnostic, Pantin, France) incubated for $48 \mathrm{~h}$ at $30^{\circ} \mathrm{C}$.

\subsection{Chemical analyses}

\subsubsection{Lactic and acetic acid contents}

L-Lactate, D-lactate and acetic acid contents in microfiltered milk and TS buffered medium were determined using the spectrometric method as recommended in the Kits EnzyPlus of Diffchamb (Kits EnzyPlus Diffchamb, SARL, Lyon, France). Results were expressed in $\mathrm{gl}^{-1}$ of microfiltered milk.

\subsubsection{Amino acid analyses}

To analyze amino acids in microfiltered milk cultures, the proteins were precipitated by adding four volumes of methanol to one volume of samples followed by overnight incubation on ice. Then the mixture was centrifuged and the supernatant was kept for amino acid analyses. Free amino acids in the medium were measured by HPLC (HP 1090, Hewlett-Packard, Waldbronn, Germany). The amino acids were automatically derived with OrthoPhtalic Aldehyd (OPA) (Sigma-Aldrich, Steinheim, Germany) and 9-fluorenylmethyl-chloroformiate (FMOC-C1) (SigmaAldrich). The metabolites were separated on column Hypersil C18 (Thermo Hypersil, Cheshire, UK) at $35^{\circ} \mathrm{C}$ by a linear gradient of acetate buffer ( $\mathrm{pH}$ 7.2)-EDTAtriethyl aminetetrahydrofuranne and gradient of acetate buffer ( $\mathrm{pH}$ 7.2)-methanol-acetonitrile.

Two detectors were used in parallel; the first one was a diode bar spectrophotometer at $338 \mathrm{~nm}$ for OPA derivatives and $262 \mathrm{~nm}$ for FMOC derivatives.

\subsection{Antistaphylococcal properties of the supernatant}

An agar well-diffusion assay, as described by Hernandez et al. (2005), was used for the detection of antistaphylococcal activity in the supernatants of co-cultures of $S$. aureus with Lactococcus or Enterococcus strains in TS buffered medium. The method was modified as following; M17 agar plates $(1.5 \%$ agar) were overlaid with $10 \mathrm{ml}$ of BHI agar $(0.75 \%$ agar), inoculated with $100 \mu \mathrm{l}$ of an overnight culture of $S$. aureus. The samples of 6 and $24 \mathrm{~h}$ old co-cultures of Lactococcus or Enterococcus strains with $S$. aureus in TS buffered medium were centrifuged to $9600 \times g$ for $15 \mathrm{~min}$ at $4{ }^{\circ} \mathrm{C}$. The co-culture supernatants were concentrated to $1 \times 10^{-1}$ of their original volume using an ultrafiltration spin column (Vivaspin, VIVASCIENCE, Hannover, Germany) with a 3000 Da pore size membrane. The concentrated supernatant was deposited in the agar plate wells. The zone of inhibition was visually examined.

\subsection{Statistical analysis}

$\mathrm{pH}$ values, lactate, acetate and amino acid contents in microfiltered milk at 3,6 and $24 \mathrm{~h}$ of incubation, were analyzed by analysis of variance (ANOVA). When the differences were significant, a Newman Keuls test was performed. Statistical correlations between $\mathrm{pH}$ values and $S$. aureus counts in microfiltered milk were carried out by calculating Pearson's correlation coefficient. All the analysis was performed with the software StatSoft (StatSoft, Inc., Tulsa, OK, USA).

\section{Results}

\subsection{Effect of initial $p H$ values on $S$. aureus growth}

The effect of initial $\mathrm{pH}$ value on $S$. aureus growth in microfiltered milk was evaluated (Fig. 1). The $S$. aureus count at 3,6 and $24 \mathrm{~h}$ was similar for initial $\mathrm{pH}$ values between 6.0 and 6.65 . After $6 \mathrm{~h}$ of incubation, the $S$. aureus counts were significantly lower in milk initially adjusted at $\mathrm{pH} 5.60$ and 5.78 than those adjusted at $\mathrm{pH}$ values above 6.0. At $24 \mathrm{~h}$, whatever the initial $\mathrm{pH}$, there was not significant difference in $S$. aureus counts, even at pH 5.6.

\subsection{Effect of lactic acid bacteria inoculation on S. aureus count}

The effect of LAB strains on $S$. aureus counts in microfiltered milks is indicated in Table 1. Without LAB inoculation, $S$. aureus grew through the incubation period to $7.01 \log _{10} \mathrm{CFU} \mathrm{ml} l^{-1}$ at $24 \mathrm{~h}$. At $3 \mathrm{~h}$, the level of $S$. aureus was significantly the highest in the medium inoculated with $S$. aureus alone. The lowest count similar to the level at $0 \mathrm{~h}$ was found in the media inoculated with the two L. garvieae strains (Tan1 or Tan2). At $6 \mathrm{~h}$, the level of $S$. aureus was significantly lower in co-cultures with LAB strains. No growth occurred between 3 and $24 \mathrm{~h}$ in the media inoculated with L. lactis (N650, N658 and N688) or E. faecalis N516; whereas the $S$. aureus population increased by $3.5 \log _{10}$ in the media without inoculation and by less than $1.2 \log _{10}$ in those with $L$. garvieae strains.

There were significant differences in $S$. aureus counts after $24 \mathrm{~h}$ of incubation, depending on the LAB strains inoculated. At $24 \mathrm{~h}$, the $S$. aureus counts in milks inoculated with $L$. garvieae strains (N201, Tan 1, Tan 2, and 1204) $\left(<4.4 \log _{10}\right)$ were higher than that in the medium with L. lactis (N650, N658 and N688) or E. faecalis N516 $\left(<3.17 \log _{10}\right)$ but significantly lower than that in the control without inoculation $\left(7.01 \log _{10}\right)$.

At $6 \mathrm{~h}$, the $\mathrm{pH}$ of milk inoculated with L. lactis or E. faecalis was significantly lower than that found in the two milk samples inoculated with $S$. aureus alone and with $S$. aureus and L. garvieae (Table 1 ). After $6 \mathrm{~h}$ of incubation $\mathrm{pH}$ values in milks inoculated with $L$. garvieae were lower than that inoculated with $S$. aureus alone, although the difference was not statistically significant. At $24 \mathrm{~h}$, the $\mathrm{pH}$ 


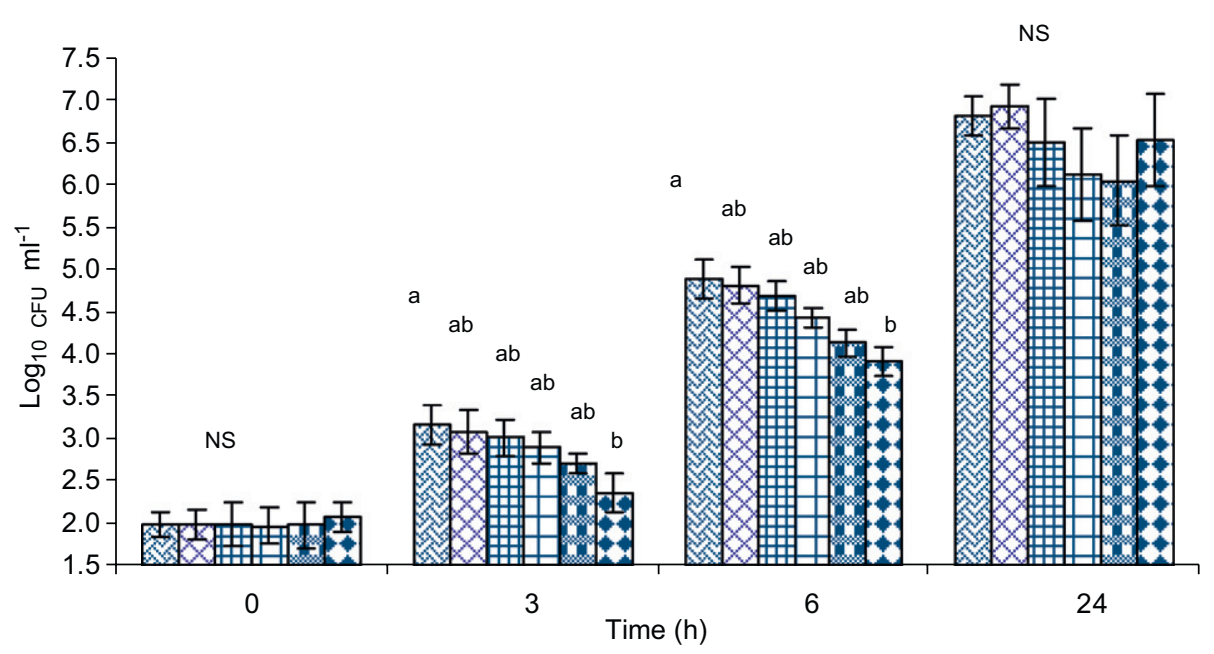

Fig. 1. Effect of $\mathrm{pH}$ values on $S$. aureus count in microfiltered milk after 3,6 and $24 \mathrm{~h}$ of incubation at $33^{\circ} \mathrm{C}$. Values are the means of three experiments. At the same time, letters ( $\mathrm{a}$ and $\mathrm{b}$ ) indicate homogeneous statistical processing groups. Numbers with different letters are not equal; $\mathrm{a}$ and $\mathrm{b}$ are classified in decreasing order $(\mathrm{a}>\mathrm{b})$. For each time of incubation $(0,3,6$ and $24 \mathrm{~h})$, means with different letters were significantly different by Newman-Keuls statistical test; the significant of the test (NS, non-significant; $P<0.01)$. pH values: $6.65 ; \square 6.5 ; 6.25 ;$ 田 $6.00 ; 5.78 ; 5.60$.

Table 1

S. aureus SA15 and lactic acid bacteria (LAB) counts with pH values following S. aureus SA15 and Lactococcus or Enterococcus strain co-culture in microfiltered milk

\begin{tabular}{|c|c|c|c|c|c|c|c|c|c|}
\hline Time & $\begin{array}{l}\text { S. aureus } \\
\text { SA15 }\end{array}$ & \multicolumn{8}{|c|}{ Co-culture of $S$. aureus SA15 with different strains of LAB in microfiltered milk } \\
\hline 0 & $2.22 \pm 0.04$ & $2.17 \pm 0.12$ & $2.19 \pm 0.12$ & $2.15 \pm 0.07$ & $2.14 \pm 0.23$ & $2.19 \pm 0.18$ & $2.14 \pm 0.14$ & $2.17 \pm 0.06$ & $2.15 \pm 0.13$ \\
\hline 3 & $3.48 \pm 0.28 \mathrm{a}$ & $3.04 \pm 0.40 \mathrm{ab}$ & $3.04 \pm 0.29 \mathrm{ab}$ & $2.96 \pm 0.24 \mathrm{ab}$ & $3.01 \pm 0.22 \mathrm{ab}$ & $3.13 \pm 0.25 \mathrm{ab}$ & $2.93 \pm 0.20 \mathrm{ab}$ & $2.73 \pm 0.27 b$ & $2.72 \pm 0.15 b$ \\
\hline 6 & $4.45 \pm 0.19 \mathrm{a}$ & $3.20 \pm 0.23 b$ & $3.23 \pm 0.33 b$ & $3.16 \pm 0.37 b$ & $3.12 \pm 0.25 b$ & $3.58 \pm 0.18 b$ & $3.43 \pm 0.30 b$ & $3.07 \pm 0.31 b$ & $3.19 \pm 0.24 b$ \\
\hline 24 & $7.01 \pm 0.04 \mathrm{a}$ & $3.11 \pm 0.23 \mathrm{c}$ & $3.06 \pm 0.17 \mathrm{c}$ & $3.17 \pm 0.43 \mathrm{c}$ & $3.18 \pm 0.29 \mathrm{c}$ & $4.32 \pm 0.41 b$ & $3.85 \pm 0.36 b c$ & $3.94 \pm 0.72 b c$ & $3.66 \pm 0.36 b c$ \\
\hline 0 & $0.00 \pm 0.00$ & $8.09 \pm 0.12$ & $8.11 \pm 0.08$ & $8.17 \pm 0.22$ & $8.20 \pm 0.20$ & $8.05 \pm 0.08$ & $8.14 \pm 0.13$ & $8.12 \pm 0.12$ & $8.15 \pm 0.08$ \\
\hline 3 & $0.00 \pm 0.00$ & $8.96 \pm 0.21$ & $8.89 \pm 0.43$ & $9.00 \pm 0.20$ & $9.01 \pm 0.23$ & $8.69 \pm 0.36$ & $8.62 \pm 0.38$ & $8.57 \pm 0.32$ & $8.70 \pm 0.27$ \\
\hline 6 & $0.00 \pm 0.00$ & $9.28 \pm 0.19 \mathrm{ab}$ & $9.42 \pm 0.16 \mathrm{a}$ & $9.44 \pm 0.09 \mathrm{a}$ & $9.70 \pm 0.28 \mathrm{a}$ & $9.05 \pm 0.08 \mathrm{ab}$ & $8.67 \pm 0.48 b$ & $9.10 \pm 0.36 \mathrm{ab}$ & $8.98 \pm 0.28 \mathrm{ab}$ \\
\hline 24 & $0.00 \pm 0.00$ & $9.90 \pm 0.46 \mathrm{ab}$ & $9.52 \pm 0.28 \mathrm{ab}$ & $10.07 \pm 0.4 \mathrm{a}$ & $10.13 \pm 0.2 \mathrm{a}$ & $9.38 \pm 0.5 \mathrm{ab}$ & $9.04 \pm 0.25 b$ & $9.27 \pm 0.46 \mathrm{ab}$ & $8.92 \pm 0.45 b$ \\
\hline \multicolumn{10}{|c|}{$\mathrm{pH}$ values } \\
\hline 0 & $6.72 \pm 0.04$ & $6.72 \pm 0.04$ & $6.72 \pm 0.04$ & $6.72 \pm 0.04$ & $6.72 \pm 0.04$ & $6.72 \pm 0.04$ & $6.72 \pm 0.04$ & $6.72 \pm 0.04$ & $6.72 \pm 0.04$ \\
\hline
\end{tabular}

The results of bacterial count are expressed as $\log _{10} \mathrm{CFU} \mathrm{ml}^{-1}$ of microfiltered milk. Values are the means of three experiments with each strain. In the same line, letters (a, b, c, d and e) indicate homogeneous statistical processing groups. Numbers with different letters are not equal; a, b, c, d and e are classified in decreasing order $(a>b>c>d>e)$. For each time of incubation $(0,3,6$ and $24 \mathrm{~h})$, means in the same line with different letters were significantly different by Newman-Keuls statistical test; the significant of the test (no letter, non-significant; $P<0.05$ ).

value of the milk inoculated with $L$. garvieae was significantly lower than that found in milk with $S$. aureus alone.

\subsection{Amino acid content and $S$. aureus count}

Amino acids were quantified in the culture supernatants from microfiltered milk samples inoculated with $S$. aureus alone or with $L$. garvieae $\mathrm{N} 201, L$. lactis $\mathrm{N} 658$ or $E$. faecalis N516 (Table 2).
Arginine, cysteine and tryptophan were never detected in non-inoculated or inoculated milk at any time during incubation.

At 6 and $24 \mathrm{~h}$, supernatants of co-cultures with L. lactis or E. faecalis strains were characterized by the highest levels of aspartic acid, glutamic acid, histidine, valine, methionine, isoleucine, phenylalanine, alanine, tyrosine, leucine, lysine, proline even if the level of valine, methionine and leucine tended to decrease between 6 and $24 \mathrm{~h}$. The decrease in valine, methionine, alanine and leucine was particularly 
Table 2

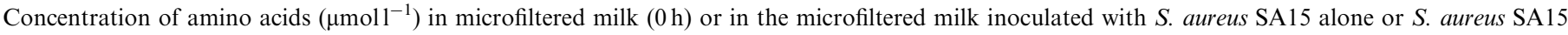
with L. garvieae (N201), L. lactis subsp. lactis (N658), or E. faecalis (N516) at 3, 6 and $24 \mathrm{~h}$

\begin{tabular}{|c|c|c|c|c|c|c|c|c|c|c|c|c|c|}
\hline \multirow{3}{*}{ Time } & \multirow{3}{*}{$\frac{\mathrm{Oh}}{\mathrm{Milk}}$} & \multicolumn{4}{|l|}{$3 \mathrm{~h}$} & \multicolumn{4}{|l|}{$6 \mathrm{~h}$} & \multicolumn{4}{|l|}{$24 \mathrm{~h}$} \\
\hline & & \multirow{2}{*}{$\begin{array}{l}\text { S. aureus } \\
\text { SA15 }\end{array}$} & \multicolumn{3}{|c|}{ SA15 in co-culture with } & \multicolumn{4}{|c|}{ SA15 in co-culture with } & \multicolumn{4}{|c|}{ SA15 in co-culture with } \\
\hline & & & $\begin{array}{l}\text { L. garvieae } \\
\text { N201 }\end{array}$ & $\begin{array}{l}\text { L. lactis } \\
\text { N658 }\end{array}$ & $\begin{array}{l}\text { E. faecalis } \\
\text { N516 }\end{array}$ & $\begin{array}{l}\text { S. aureus } \\
\text { SA15 }\end{array}$ & $\begin{array}{l}\text { L. garvieae } \\
\text { N201 }\end{array}$ & $\begin{array}{l}\text { L. lactis } \\
\text { N658 }\end{array}$ & $\begin{array}{l}\text { E. faecalis } \\
\text { N516 }\end{array}$ & $\begin{array}{l}\text { S. aureus } \\
\text { SA15 }\end{array}$ & $\begin{array}{l}\text { L. garvieae } \\
\text { N201 }\end{array}$ & $\begin{array}{l}\text { L. lactis } \\
\text { N658 }\end{array}$ & $\begin{array}{l}\text { E. faecalis } \\
\text { N516 }\end{array}$ \\
\hline Asp & $15 \pm 2$ & $11 \pm 2 b$ & $20 \pm 4 b$ & $63 \pm 2 \mathrm{a}$ & $59 \pm 11 \mathrm{a}$ & $14 \pm 2 b$ & $25 \pm 3 b$ & $60 \pm 9 a$ & $64 \pm 13 a$ & $12 \pm 3 d$ & $25 \pm 5 c$ & $58 \pm 6 a$ & $45 \pm 3 b$ \\
\hline Glu & $298 \pm 18$ & $287 \pm 11$ & $310 \pm 23$ & $405 \pm 103$ & $396 \pm 106$ & $275 \pm 11 b$ & $289 \pm 11 b$ & $540 \pm 106 a$ & $595 \pm 97 a$ & $274 \pm 23 c$ & $282 \pm 22 c$ & $693 \pm 57 a$ & $590 \pm 72 b$ \\
\hline His & $0 \pm 0$ & $0 \pm 0 \mathrm{~b}$ & $0 \pm 0 \mathrm{~b}$ & $26 \pm 11 \mathrm{a}$ & $4 \pm 8 b$ & $0 \pm 0 \mathrm{~b}$ & $0 \pm 0 b$ & $31 \pm 5 a$ & $6 \pm 11 b$ & $0 \pm 0 \mathrm{c}$ & $3 \pm 6 c$ & $31 \pm 8 \mathrm{a}$ & $20 \pm 4 b$ \\
\hline Gly & $91 \pm 9$ & $88 \pm 8$ & $86 \pm 34$ & $41 \pm 28$ & $54 \pm 5$ & $91 \pm 5 a$ & $62 \pm 13 b$ & $22 \pm 5 c$ & $61 \pm 17 b$ & $118 \pm 22 \mathrm{a}$ & $43 \pm 11 b$ & $12 \pm 11 b$ & $44 \pm 16 b$ \\
\hline Val & $17 \pm 2$ & $18 \pm 1$ & $26 \pm 2$ & $64 \pm 48$ & $53 \pm 31$ & $17 \pm 0 b$ & $18 \pm 6 b$ & $99 \pm 26 a$ & $83 \pm 25 a$ & $17 \pm 1 \mathrm{c}$ & $7 \pm 6 d$ & $55 \pm 3 a$ & $26 \pm 2 b$ \\
\hline Met & $4 \pm 7$ & $4 \pm 8$ & $4 \pm 8$ & $30 \pm 12$ & $15 \pm 16$ & $0 \pm 0 b$ & $0 \pm 0 b$ & $40 \pm 8 \mathrm{a}$ & $20 \pm 18 b$ & $0 \pm 0 \mathrm{~b}$ & $0 \pm 0 b$ & $18 \pm 1 a$ & $0 \pm 0 b$ \\
\hline Ile & $17 \pm 3$ & $14 \pm 5$ & $18 \pm 2$ & $23 \pm 11$ & $16 \pm 15$ & $15 \pm 2 b$ & $10 \pm 9 b$ & $33 \pm 8 a$ & $28 \pm 5 a$ & $16 \pm 4 a b$ & $4 \pm 8 b$ & $21 \pm 7 a$ & $17 \pm 1 a b$ \\
\hline Phe & $4 \pm 8$ & $11 \pm 2 b$ & $14 \pm 1 b$ & $41 \pm 20 a$ & $43 \pm 8 a$ & $12 \pm 2 c$ & $12 \pm 2 c$ & $72 \pm 8 a$ & $56 \pm 9 b$ & $12 \pm 2 c$ & $3 \pm 6 d$ & $50 \pm 4 a$ & $28 \pm 3 b$ \\
\hline Thr & $7 \pm 7$ & $10 \pm 1$ & $0 \pm 0$ & $7 \pm 6$ & $3 \pm 5$ & $10 \pm 1 \mathrm{a}$ & $0 \pm 0 \mathrm{~b}$ & $10 \pm 2 a$ & $4 \pm 8 \mathrm{ab}$ & $3 \pm 5$ & $0 \pm 0$ & $10 \pm 1$ & $10 \pm 9$ \\
\hline Ser & $19 \pm 3$ & $19 \pm 4$ & $27 \pm 6$ & $49 \pm 39$ & $31 \pm 18$ & $19 \pm 3 b$ & $20 \pm 3 b$ & $47 \pm 15 \mathrm{a}$ & $36 \pm 27 a b$ & $14 \pm 3$ & $18 \pm 4$ & $22 \pm 3$ & $22 \pm 5$ \\
\hline Ala & $38 \pm 5$ & $36 \pm 4$ & $43 \pm 6$ & $108 \pm 56$ & $113 \pm 32$ & $37 \pm 2 b$ & $35 \pm 7 b$ & $145 \pm 18 \mathrm{a}$ & $156 \pm 74 a$ & $34 \pm 3$ & $34 \pm 10$ & $49 \pm 1$ & $48 \pm 14$ \\
\hline Tyr & $0 \pm 0$ & $0 \pm 0$ & $0 \pm 0$ & $79 \pm 56$ & $22 \pm 39$ & $0 \pm 0 \mathrm{~b}$ & $0 \pm 0 \mathrm{~b}$ & $148 \pm 17 a$ & $57 \pm 10 b$ & $0 \pm 0 \mathrm{c}$ & $0 \pm 0 \mathrm{c}$ & $114 \pm 5 a$ & $44 \pm 13 b$ \\
\hline Nva & $58 \pm 5$ & $61 \pm 5 a$ & $60 \pm 1 a$ & $61 \pm 11 \mathrm{a}$ & $15 \pm 18 b$ & $64 \pm 11 a$ & $59 \pm 6 a$ & $61 \pm 4 a$ & $13 \pm 9 b$ & $66 \pm 7 a$ & $59 \pm 7 a$ & $61 \pm 6 a$ & $21 \pm 25 b$ \\
\hline Leu & $12 \pm 2$ & $14 \pm 1$ & $21 \pm 2$ & $103 \pm 104$ & $94 \pm 54$ & $16 \pm 4 b$ & $15 \pm 3 b$ & $203+29 a$ & $188 \pm 316 a$ & $14 \pm 2 c$ & $13 \pm 1 c$ & $124 \pm 9 a$ & $72 \pm 7 b$ \\
\hline Lys & $0 \pm 0$ & $0 \pm 0$ & $0 \pm 0$ & $130 \pm 132$ & $109 \pm 96$ & $0 \pm 0 b$ & $0 \pm 0 \mathrm{~b}$ & $265 \pm 2 a$ & $236 \pm 18 \mathrm{a}$ & $0 \pm 0 \mathrm{c}$ & $0 \pm 0 \mathrm{c}$ & $268 \pm 18 \mathrm{a}$ & $217 \pm 19 b$ \\
\hline Pro & $0 \pm 0$ & $0 \pm 0 b$ & $0 \pm 0 b$ & $364 \pm 151 a$ & $391 \pm 130 a$ & $0 \pm 0 b$ & $0 \pm 0 b$ & $552 \pm 152 \mathrm{a}$ & $544 \pm 57 a$ & $0 \pm 0 b$ & $0 \pm 0 b$ & $492 \pm 143 a$ & $508 \pm 109 a$ \\
\hline
\end{tabular}

Values are the mean of three experiments with each strain. In the same line for each incubation time, 3, 6 and $24 \mathrm{~h}$, the letters (a, b, c and d) indicate homogeneous statistical processing groups for each amino acid for $P<0.05$ or $P<0.01$ ). Numbers with different letters are not equal; a, b, c and d are classified in decreasing order $(a>b>c>d)$. For each time of incubation (3, 6 and $24 \mathrm{~h})$, means in the same line with different letters were significantly different by Newman-Keuls statistical test; the significant of the test (no letter, non-significant). Limit of detection was $10 \mu$ mol $1^{-1}$. Arginine, tryptophan and cysteine were never detected in microfiltered milk at $0 \mathrm{~h}$ or in inoculated milk with $S$. aureus alone or with LAB at any time during incubation. Asp, aspartic acid; Glu, glutamic acid; His, histidine; Gly, glycine; Val, valine; Met, methionine; Ile, isoleucine; Phe, phenylalanine; Thr, threonine; Ser, serine; Ala, alanine; Tyr, tyrosine; Nva, norvaline; Leu, leucine; Lys, lysine; Pro, proline.

marked between 6 and $24 \mathrm{~h}$ and was the strongest with $E$. faecalis. In contrast, the 6 and $24 \mathrm{~h}$ media inoculated with $S$. aureus alone or $S$. aureus and $L$. garvieae exhibited the lowest concentration of these amino acids. Histidine, tyrosine, lysine and proline were not detected in microfiltered milk at $0 \mathrm{~h}$ or during the incubation in the media inoculated with $S$. aureus alone. Glycine content decreased during incubation in media with Lactococcus or Enterococcus strains, markedly so with $L$. lactis. In medium inoculated with $L$. garvieae, valine, methionine, isoleucine and threonine contents tended to decrease throughout the incubation period, and were the lowest after $24 \mathrm{~h}$. In medium inoculated with $S$. aureus alone, the amino acid contents of aspartic acid, glutamic acid, glycine, valine, isoleucine, serine, alanine, norvaline and leucine did not change a lot $\left(<10 \mu \mathrm{moll}^{-1}\right)$ throughout the incubation.

Adding $10 \mu \mathrm{mol} 1^{-1}$ of each amino acid, valine, methionine, isoleucine, phenylalanine and threonine to the microfiltered milk did not modify $S$. aureus or L. garvieae N201 growth and did not modify $\mathrm{pH}$ values. It did not suppress the inhibition by $L$. garvieae N201.

\subsection{S. aureus count and the concentration of lactate and acetate in microfiltered milk}

After $24 \mathrm{~h}$ of incubation, concentrations of D-lactate and of acetate were very low $\left(<0.5 \mathrm{gl}^{-1}\right)$ in microfiltered milk inoculated with $S$. aureus and L. lactis N658 or E. faecalis N516. L-Lactate, D-lactate and acetate were not detected in microfiltered milk inoculated with $S$. aureus alone or in coculture with $L$. garvieae N201. At 24 h, L-lactate was only measured in milk inoculated with strains of L. lactis or E. faecalis at concentrations $6.3 \mathrm{gl}^{-1}$ (Table 3).

At $6 \mathrm{~h}$, the $S$. aureus count was slightly correlated with milk $\mathrm{pH}$ values $(r=0.29 ; p<0.05, n=27)$. At $24 \mathrm{~h}$, there was a positive correlation between the $\mathrm{pH}$ values and $S$. aureus count $(r=0.74 ; p<0.05, n=27)$.

\subsection{Effect of Lactococcus or Enterococcus strains on S. aureus growth in buffered media}

In TS medium buffered at $\mathrm{pH} 6.8$, the differences in $S$. aureus count between the control and co-culture assays were not statistically significant 3 and $6 \mathrm{~h}$ after inoculation. The $S$. aureus count (around $4 \mathrm{log}$ ) was significantly lower only after $24 \mathrm{~h}$ of incubation in the medium inoculated with Lactococcus or Enterococcus strains than in that with $S$. aureus alone $(5 \mathrm{log})$ (Table 4). The growth of $S$. aureus was lower in TS medium than in microfiltred milk ( $7 \log$ at $24 \mathrm{~h}$ ). The $\mathrm{pH}$ of all media remained stable at 6.8 throughout the incubation, with or without LAB. L-Lactate, D-lactate or acetate was not detected in the supernatants of cultures inoculated with $S$. aureus alone or with the LAB throughout the incubation. 
Table 3

L-Acid lactic, D-acid lactic, acetic acid contents $\left(\mathrm{g}^{-1}\right)$ in microfiltered milk inoculated with S. aureus SA15 alone and in co-culture with $L$. garvieae (N201), L. lactis subsp. lactis (N658), or E. faecalis (N516)

\begin{tabular}{|c|c|c|c|c|c|c|c|c|c|}
\hline Time & \multicolumn{3}{|l|}{ L-Lactate } & \multicolumn{3}{|l|}{ D-Lactate } & \multicolumn{3}{|l|}{ Acetic acid } \\
\hline S. aureus SA15 & $0.01 \pm 0.01 \mathrm{~b}$ & $0.02 \pm 0.03 b$ & $0.01 \pm 0.01 b$ & $0.00 \pm 0.00$ & $0.00 \pm 0.00$ & $0.00 \pm 0.00$ & $0.02 \pm 0.01 \mathrm{~d}$ & $0.03 \pm 0.01 \mathrm{c}$ & $0.02 \pm 0.01 \mathrm{c}$ \\
\hline S. aureus $S A 15+L$. garvieae $\mathrm{N} 201$ & $0.39 \pm 0.07 \mathrm{~b}$ & $0.49 \pm 0.12 b$ & $0.90 \pm 0.17 b$ & $0.00 \pm 0.00$ & $0.00 \pm 0.00$ & $0.00 \pm 0.00$ & $0.05 \pm 0.01 \mathrm{c}$ & $0.04 \pm 0.02 \mathrm{c}$ & $0.04 \pm 0.00 \mathrm{c}$ \\
\hline S. aureus $S A 15+L$. lactis $\mathrm{N} 658$ & $1.94 \pm 0.89 \mathrm{a}$ & $3.63 \pm 0.60 \mathrm{a}$ & $6.36 \pm 2.05 \mathrm{a}$ & $0.23 \pm 0.01$ & $0.19 \pm 0.15$ & $0.34 \pm 0.19 \mathrm{a}$ & $0.39 \pm 0.03 \mathrm{a}$ & $0.41 \pm 0.02 \mathrm{a}$ & $0.37 \pm 0.03 \mathrm{a}$ \\
\hline S. aureus $S A 15+E$. faecalis N516 & $1.31 \pm 0.13 \mathrm{a}$ & $4.42 \pm 0.60 \mathrm{a}$ & $6.37 \pm 1.55 \mathrm{a}$ & $0.21 \pm 0.12$ & $0.19 \pm 0.08$ & $0.12 \pm 0.01 \mathrm{~b}$ & $0.12 \pm 0.01 \mathrm{~b}$ & $0.14 \pm 0.02 b$ & $0.17 \pm 0.01 b$ \\
\hline$P$ & $* *$ & $* *$ & $* *$ & $\mathrm{NS}^{-}$ & NS & $*-$ & $* *$ & $* *-$ & $* *-$ \\
\hline
\end{tabular}

Values are the mean of three experiments with each strain. In the same column, letters (a, b, c and d) indicate homogeneous statistical processing groups. Numbers with different letters are not equal; $a, b, c$ and $d$ are classified in decreasing order $(a>b>c>d)$. For each time of incubation $(3,6$ and $24 \mathrm{~h}$ ), means in the same column with different letters were significantly different by Newman-Keuls statistical test; the significant of the test. NS, nonsignificant.

$* P<0.05$.

${ }^{* *} P<0.01$

Table 4

Counts of S. aureus SA15, L. garvieae (N201), L. lactis subsp. lactis (N658), and E. faecalis (N516) in TS-buffered medium

\begin{tabular}{|c|c|c|c|c|c|c|c|c|}
\hline \multirow[t]{2}{*}{ Time (h) } & \multicolumn{4}{|c|}{ S. aureus $\mathrm{SA} 15$ counts $\left(\log _{10} \mathrm{CFU} \mathrm{ml}{ }^{-1}\right)$} & \multicolumn{4}{|c|}{ Lactic acid bacteria counts $\left(\log _{10} \mathrm{CFU} \mathrm{ml}{ }^{-1}\right)$} \\
\hline & 0 & 3 & 6 & 24 & 0 & 3 & 6 & 24 \\
\hline S. aureus SA15 & $2.25 \pm 0.05$ & $2.98 \pm 0.30$ & $3.44 \pm 0.22$ & $5.05 \pm 0.27 \mathrm{a}$ & $0.00 \pm 0.00$ & $0.00 \pm 0.00$ & $0.00 \pm 0.00$ & $0.00 \pm 0.00$ \\
\hline $\mathrm{SA} 15+$ L. garvieae $\mathrm{N} 201$ & $2.19 \pm 0,12$ & $2.84 \pm 0.27$ & $3.04 \pm 0.30$ & $3.78 \pm 0.21 b$ & $8.12 \pm 0.12$ & $9.25 \pm 0.57$ & $9.28 \pm 0.59$ & $9.46 \pm 0.39$ \\
\hline $\mathrm{SA} 15+$ L. lactis $\mathrm{N} 658$ & $2.24 \pm 0.09$ & $2.88 \pm 0.42$ & $3.10 \pm 0.35$ & $3.77 \pm 0.05 b$ & $8.14 \pm 0.21$ & $9.27 \pm 0.43$ & $9.33 \pm 0.33$ & $9.57 \pm 0.38$ \\
\hline $\mathrm{SA} 15+$ E. faecalis $\mathrm{N} 516$ & $2.22 \pm 0.11$ & $3.00 \pm 0.11$ & $3.35 \pm 0.16$ & $4.06 \pm 0.17 \mathrm{~b}$ & $8.09 \pm 0.19$ & $9.22 \pm 0.41$ & $9.23 \pm 0.21$ & $9.29 \pm 0.47$ \\
\hline
\end{tabular}

Values are the mean of three experiments with each strain. In the same column, letters (a and b) indicate homogeneous statistical processing groups; a and $\mathrm{b}$ are classified in decreasing order $(\mathrm{a}>\mathrm{b})$. For each time of incubation $(3,6$ and $24 \mathrm{~h})$, means in the same column with different letters were significantly different by Newman-Keuls statistical test; the significant of the test (no letter, non-significant, $P<0.05$ ).

The concentrated supernatants of the co-culture of L. garvieae N201, L. lactis $\mathrm{N} 658$ and E. faecalis N516 with $S$. aureus in TS buffered medium after 6 and $24 \mathrm{~h}$ of incubation did not produce any inhibition zone against $S$. aureus tested on agar plate according to the method of Hernandez et al. (2005).

\section{Discussion}

S. aureus was inhibited by L. lactis, E. faecalis and L. garvieae from $6 \mathrm{~h}$ of incubation in microfiltered milk and only at $24 \mathrm{~h}$ in TS medium buffered at $\mathrm{pH} 6.8 \mathrm{pH}$ values can be involved in the inhibition by L. lactis and E. faecalis as the $\mathrm{pH}$ drop at values inhibiting $S$. aureus. $\mathrm{pH}$ has been often described as an important factor to control $S$. aureus in cheese. Indeed, Meyrand et al. (1999) reported that S. aureus was inhibited in lactic goat cheeses with a $\mathrm{pH} 4.5$ at the end of draining. In the same way, the growth of $S$. aureus in non-cooked semi-hard cheeses was dependant on the $\mathrm{pH}$ values (Delbes et al., 2006). Stecchini et al. (1991) indicated that the inhibitory effect of the starter culture on $S$. aureus growth was not only due to the decrease in $\mathrm{pH}$.

Other factors can be involved in the inhibition as this occur at $\mathrm{pH} 6.8$, especially with $L$. garvieae. Moreover,
L. garvieae produced slight quantity of lactate and no acetate.

In our study, the inhibition could not be due to the production of antistaphylococcal substances in supernatant. Strains of Enterococcus and L. garvieae were able to produce bacteriocin, respectively, enterocin (Giraffa, 2003; Leroy et al., 2003) and garviecin L1-5 (Villani et al., 2001). Nevertheless, as in our study, Ammor et al. (2006) failed to detect antimicrobial substances in culture supernatants inhibiting $S$. aureus growth.

The amino acid content was not a limiting factor for $S$. aureus growth. Some aminoacids (histidine, tyrosine, lysine, proline, arginine, tryptophan and cysteine) were in low concentration in milk and nevertheless the growth was better than in TS medium with high amount of free amino acids. Complementation of milk with aminoacids metabolized by $L$. garviae did not suppress the inhibition.

Our result did not agree with the amino acid requirement described in the literature. These disagreements between our results and those from other studies could result from differences in culture media and incubation conditions. Lincoln et al. (1995) found that seven S. aureus strains required arginine, proline, cystine, valine, leucine and glycine for their growth but they performed their study in a chemically defined medium at $37^{\circ} \mathrm{C}$. The same result was 
obtained by Onoue and Mori (1997) in a chemically defined medium. Keller et al. (1978) observed that $S$. aureus could utilize glutamate, proline, histidine, aspartate, alanine, threonine, serine or glycine as a major energy source.

\section{Acknowledgements}

The authors would like to thank Jean Bernard Millière for his helpful advices and Harriet Coleman for English proofreading.

\section{Reference}

Ammor, S., Tauveron, G., Dufour, E., Chevallier, I., 2006. Antibacterial activity of lactic acid bacteria against spoilage and pathogenic bacteria isolated from the same meat small-scale facility. 1. Screening and characterization of the antibacterial compounds. Food Control 17, 454-461.

Arques, J.L., Rodriguez, E., Gaya, P., Medina, M., Guamis, B., Nunez, M., 2005. Inactivation of Staphylococcus aureus in raw milk cheese by combinations of high-pressure treatments and bacteriocin-producing lactic acid bacteria. J. Appl. Microbiol. 98, 254-260.

Callon, C., Millet, L., Montel, M.C., 2004. Diversity of lactic acid bacteria isolated from AOC Salers cheese. J. Dairy Res. 71, 231-244.

Callon, C., Berdagué, J.L., Dufour, E., Montel, M.C., 2005. The effect of raw milk microbial flora on the sensory characteristics of Salers-type cheeses. J. Dairy Sci. 88, 3840-3850.

Chassagne, M., Barnouin, J., Le Guenic, M., 2005. Expert assessment study of milking and hygiene practices characterizing very low somatic cell score herds in France. J. Dairy Sci. 88, 1909-1916.

De Buyser, M.L., Dufour, B., Maire, M., Lafarge, V., 2001. Implication of milk and milk products in food-borne diseases in France and in different industrialised countries. Int. J. Food Microbiol. 67, 1-17.

De Buyser, B., Lombard, M.L., Schulten, S.M., Veld, P.H. In't, Scotter, S.L., Rollier, P., Labellec, C., 2003. Validation of EN ISO Standard methods 6888. Part 1 and 2: 1999-enumeration of coagulase-positive Staphylococci in food. Int. J. Food Microbiol. 83, 185-194.

Delbes, C., Alomar, J., Chougui, N., Martin, J.F., Montel, M.C., 2006. Staphylococcus aureus growth and enterotoxin production during manufacture of non-cooked, semi-hard cheese from cow's raw milk. J. Food Prot. 69, 2161-2167.

Feeney, E.P., Guinee, T.P., Fox, P.F., 2002. Effect of pH and calcium concentration on some textural and functional properties of mozzarella cheese. J. Dairy Sci. 85, 1646-1654.

Giraffa, G., 2003. Functionality of enterococci in dairy products. Int. J. Food Microbiol. 88, 215-222.

Hamama, A., El Hankouri, N., El Ayadi, M., 2002. Fate of enterotoxigenic Staphylococcus aureus in the presence of nisin-producing Lactococcus lactis strain during manufacture of Jben, a Moroccan traditional fresh cheese. Int. Dairy J. 12, 933-938.

Hernandez, D., Cardell, E., Zarate, V., 2005. Antimicrobial activity of lactic acid bacteria isolated from Tenerife cheese: initial characterization of plantaricin TF711, a bacteriocin-like substance produced by Lactobacillus plantarum TF711. J. Appl. Microbiol. 99, 77-84.
Jersek, B., Gilot, P., Gubina, M., 1999. Typing of Listeria monocytogenes strains by repetitive element sequence-based PCR. J. Clin. Microbiol. 37, 103-109.

Keller, G.M., Hanson, R.S., Bergdoll, M.S., 1978. Molar growth yields and enterotoxin B production of Staphylococcus aureus with amino acids as energy sources. Infect. Immun. 20, 151-157.

Lamprell, H., 2003. La production des entérotoxines dans les fromages en fonction de la diversité phénotypique et génétique des souches de Staphylococcus aureus Université de Bourgogne-Sciences de l'Alimentation-Spécialité, Microbiologie.

Leroy, F., Foulquie Moreno, M.R., De Vuyst, L., 2003. Enterococcus faecium RZS C5, an interesting bacteriocin producer to be used as a co-culture in food fermentation. Int. J. Food Microbiol. 88, 235-240.

Lincoln, R.A., Leigh, J.A., Jones, N.C., 1995. The amino acid requirements of Staphylococcus aureus isolated from cases of bovine mastitis. Vet. Microbiol. 45, 275-279.

Meyrand, A., Boutrand-Loei, S., Ray-Gueniot, S., 1998. Growth and enterotoxin production of Staphylococcus aureus during the manufacture and ripening of Camembert-type cheeses from raw goats' milk. J. Appl. Microbiol. 85, 537-544.

Meyrand, A., Vernozy-Rozand, C., Gonthier, A., Mazuy, C., RayGueniot, S., Jaubert, G., Perrin, G., Lapeyre, C., Richard, Y., 1999. Main differences in behavior and enterotoxin production of Staphylococcus aureus in two different raw milk cheeses. Revue. Méd. Vét. 150, 271-278.

Miteva, V., Ivanova, I., Budakov, I., 1998. Detection and characterization of a novel antibacterial substance produced by a Lactobacillus delbrueckii strain 1043. J. Appl. Microbiol. 85, 603-614.

Onoue, Y., Mori, M., 1997. Amino acid requirements for the growth and enterotoxin production by Staphylococcus aureus in chemically defined media. Int. J. Food Microbiol. 36, 77-82.

Sesques, M., 1994. Staphylocoques à coagulase positive dans le fromage fermier au lait cru de Saint-Nectaire: Origine, développement et risques de production d'entérotoxines. Université Claude Bernard de Lyon I.

Sommerhauser, J., Kloppert, B., Wolter, W., Zschock, M., Sobiraj, A., Failing, K., 2003. The epidemiology of Staphylococcus aureus infections from subclinical mastitis in dairy cows during a control programme. Vet. Microbiol. 96, 91-102.

Stecchini, M.L., Sarais, I., Bertoldi, M.d., 1991. The influence of Lactobacillus plantarum culture inoculation on the fate of Staphylococcus aureus and Salmonella typhimurium in Montasio cheese. Int. J. Food Microbiol. 14, 99-109.

Todorov, S., Onno, B., Sorokine, O., Chobert, J.M., Ivanova, I., Dousset, X., 1999. Detection and characterization of a novel antibacterial substance produced by Lactobacillus plantarum ST 31 isolated from sourdough. Int. J. Food Microbiol. 48, 167-177.

Villani, F., Aponte, M., Blaiotta, G., Mauriello, G., Pepe, O., Moschetti, G., 2001. Detection and characterization of a bacteriocin, garviecin L1-5, produced by Lactococcus garvieae isolated from raw cow's milk. J. Appl. Microbiol. 90, 430-439.

Zottola, E.A., Yezzi, T.L., Ajao, B.D., Roberts, R.F., 1994. Utilization of cheddar cheese containing nisin as an antimicrobial agent other foods. Int. J. Food Microbiol. 24, 227-238. 